\title{
REACTOR PERFORMANCE ON APPROACH TO POWER BY AUTOMATIC CONTROL - ENRICO FERMI REACTOR
}

M. A. Ziniuk

H. A. Wilber*

*Power Reactor Development Company 


\section{DISCLAIMER}

This report was prepared as an account of work sponsored by an agency of the United States Government. Neither the United States Government nor any agency Thereof, nor any of their employees, makes any warranty, express or implied, or assumes any legal liability or responsibility for the accuracy, completeness, or usefulness of any information, apparatus, product, or process disclosed, or represents that its use would not infringe privately owned rights. Reference herein to any specific commercial product, process, or service by trade name, trademark, manufacturer, or otherwise does not necessarily constitute or imply its endorsement, recommendation, or favoring by the United States Government or any agency thereof. The views and opinions of authors expressed herein do not necessarily state or reflect those of the United States Government or any agency thereof. 


\section{DISCLAIMER}

Portions of this document may be illegible in electronic image products. Images are produced from the best available original document. 


\section{ABSTRACT}

This report presents results of tests conducted at the Enrico Fermi reactor at power levels of 13.3,20, and $110 \mathrm{Mwt}$ for approach to power under control of the automatic loading programmer. The basic objectives of the tests were to confirm that the prescribed maximum rate of change of temperature is nowhere exceeded in the heat removal system during a programmed power increase or decrease, and that stable performance is achieved throughout the programmer operating range.

The highest rates of change of temperature obtained were $1.3 \mathrm{~F} / \mathrm{min}$ and $2.4 \mathrm{~F} / \mathrm{min}$ for the reactor outlet sodium and the core outlet sodium, respectively, while the rate of change of power was $1.2 \mathrm{Mwt} / \mathrm{min}$. A perceptible power oscillation, though well damped, was observed on level-off to 13.3 and $20 \mathrm{Mwt}$, but 1 l0 Mwt was obtained smoothly, without oscillation.

The tests have provided data that confirm that temperature transients were within established limits, and that programmer performance was satisfactory. 


\section{TABLE OF CONTENTS}

\section{$\underline{\text { Page }}$}

LIST OF ILLUSTRATIONS ................... vii

LIST OF TABLES ....................... vii

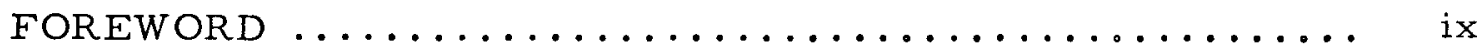

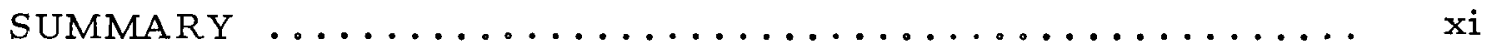

I. PURPOSE OF TEST $\ldots \ldots \ldots \ldots \ldots \ldots \ldots \ldots \ldots \ldots \ldots \ldots$

II. GENERAL DESCRIPTION OF THE ENRICO FERMI REACTOR . 3

III. EXPERIMENTAL APPARATUS A:ND EQUIPMENT $\ldots \ldots \ldots \ldots$

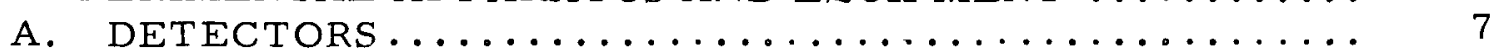

1. Reactor Outlet Temperature $(\mathrm{TE}-201) \ldots \ldots \ldots \ldots \ldots$

2. Core Outlet Temperature $(\mathrm{TE}-115) \ldots \ldots \ldots \ldots \ldots \ldots$

3. Steam Generator Sodium Inlet Temperature (TE-308) .. 10

4. Steam Generator Sodium Outlet Temperature

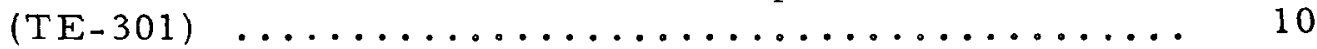

5. Reactor Inlet Temperature $(\mathrm{TE}-209) \ldots \ldots \ldots \ldots \ldots \ldots \ldots$

6. Water-Steam Temperature $(\mathrm{TE}-601) \ldots \ldots \ldots \ldots \ldots \ldots \ldots$

7. Neutron Flux ........................ 11

B. SIGNAL CONDITIONING CIRCUITS AND ADJUNCTIVE

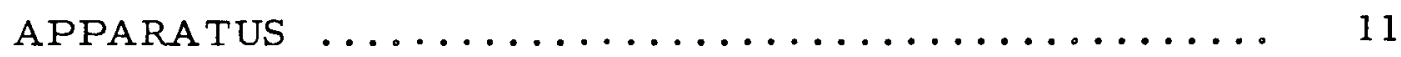

C. AUTOMATIC LOADING PROGRAMMER ........... I 15

IV. EXPERIMENTAL PROCEDURE AND PLANT CONDITIONS $\ldots . .17$

V. EXPERIMENTAL RESULTS AND ANALYSIS .............. 19

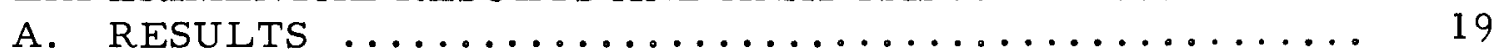

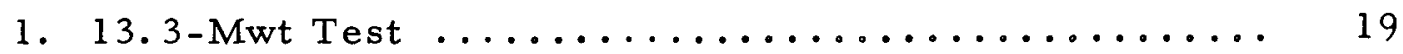

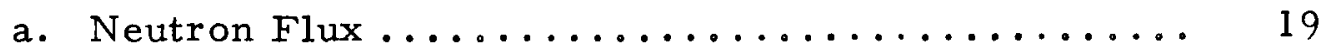

b. Neutron Flux Rate-of-Change .............. 19

c. Core Outlet Temperature $(\mathrm{TE}-115) \ldots \ldots \ldots . \ldots . \ldots 21$

d. Reactor Outlet Temperature (TE-201) .......... 21

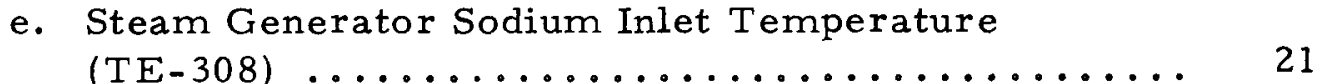

f. Reactor Inlet Sodium Temperature (TE-209) ...... 22

g. Steam Generator Sodium Outlet Temperature 
TABLE OF CONTENTS (Cont'd)

$\underline{\text { Page }}$

h. Steam Generator Steam and Water Temperature

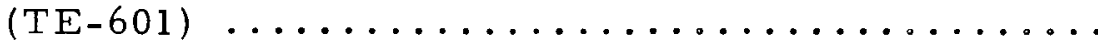

i. Regulator Rod Position, Velocity, and

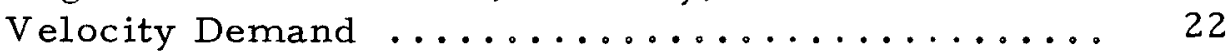

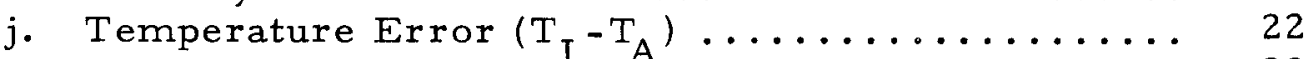

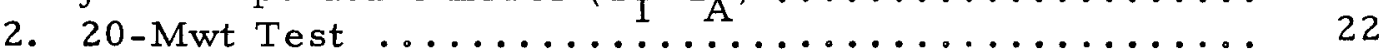

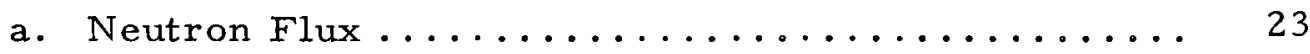

b. Neutron Flux Rate-of-Change .............. 23

c. Core Outlet Temperature (TE-115) ........... 23

d. Reactor Outlet Temperature (TE-201) ......... 23

e. Steam Generator Sodium Inlet Temperature

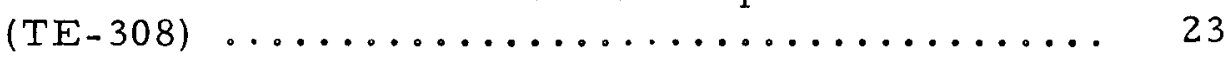

f. Reactor Inlet Sodium Temperature (TE-209) ...... 24

g. Steam Generator Sodium Outlet Temperature

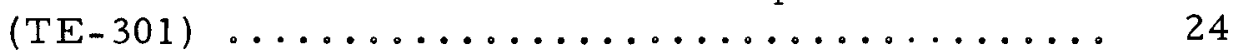

h. Steam Generator Steam and Water Temperature

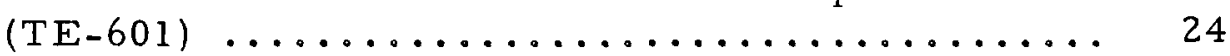

i. Regulator Rod Position, Velocity, and

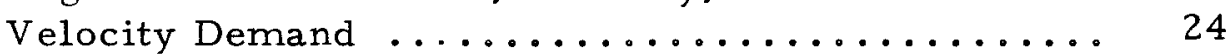

j. Temperature Error $\left(\mathrm{T}_{\mathrm{I}}-\mathrm{T}_{\mathrm{A}}\right) \ldots \ldots \ldots \ldots \ldots \ldots \ldots \ldots 24$

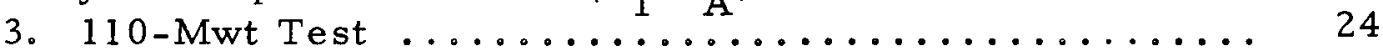

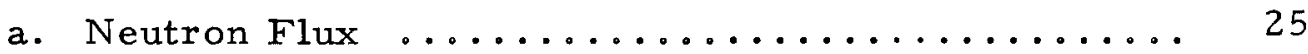

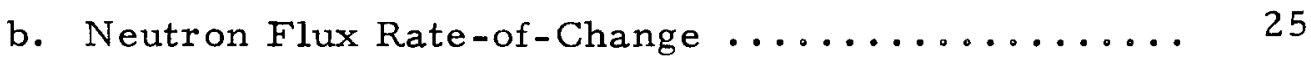

c. Core Outlet Temperature (TE-115) ........... 25

d. Reactor Outlet Temperature (TE-201) .......... 25

e. Steam Generator Sodium Inlet Temperature

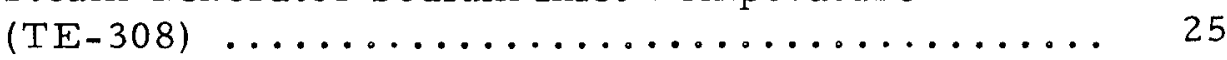

f. Reactor Inlet Sodium Temperature (TE-209) ..... 25

g. Steam Generator Sodium Outlet Temperature

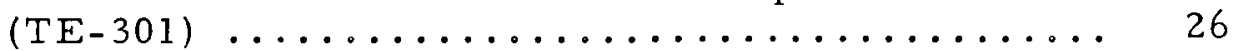

h. Steam Generator Steam and Water Temperature

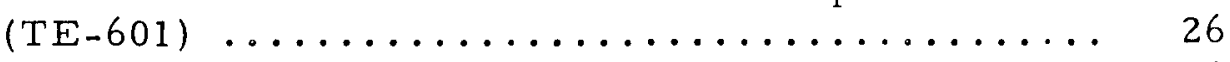

i. Regulator Rod and Shim Rod Position .......... 26

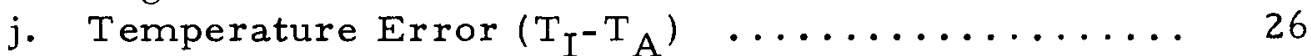

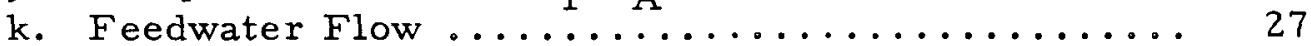

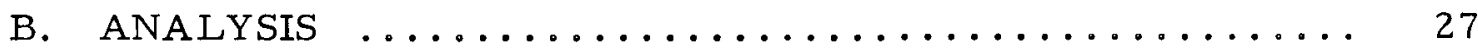

vi. CONCLUSIONS ........................... 29

REFERENCES ........................... 31 


\section{LIST OF ILLUSTRATIONS}

Fig.

Page

1. Perspective View of Reactor $\ldots \ldots \ldots \ldots \ldots \ldots \ldots$

2. Reactor Cross Section ...................... 5

3. Schematic Diagram of Temperature Detector Locations

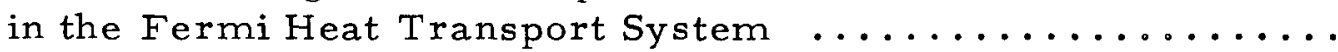

4. Location of Neutron-Counter Tubes $\ldots \ldots \ldots \ldots \ldots \ldots \ldots$

5. Bridge Circuit for Resistance Thermometer Detectors ..... 13

6. Temperature Detector Signal Circuits $\ldots \ldots \ldots \ldots \ldots \ldots \ldots$

7. Schedule of Temperature and Power Versus Time ....... 16

8. Reactor Power and Outlet Temperature Schedules

Obtained in Programmed Run-up to $110 \mathrm{Mwt}$, and

Comparison with Calculated Schedules $\ldots \ldots \ldots \ldots \ldots \ldots$

\section{LIST OF TABLES}

Table

$\underline{\text { Page }}$

1. Recorder Scale Spans Used During Test of Automatic Approach to Power at 13.3 Mwt, $20 \mathrm{Mwt}, 110 \mathrm{Mwt} . . . \ldots . .$.

2. Sodium Flow Rates in the Primary and Secondary Heat Transport Loops During the Test on Automatic Approach

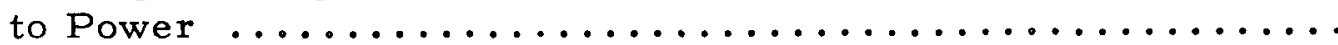




\section{FOREWORD}

This is one of a series of reports on the low-power (up to $1 \mathrm{Mwt}$ ) and high-power (up to $200 \mathrm{Mwt}$ ) nuclear testing of the Enrico Fermi reactor. The Nuclear Test Program is planned, directed, and evaluated by Atomic Power Development Associates, Inc. (APDA). The tests are conducted by Power Reactor Development Company (PRDC), who own and operate the reactor proper. The steam generators and electrical generating facilities are owned by The Detroit Edison Company (DECo.).

Many individuals have contributed to the nuclear testing of the Fermi reactor. Listed below are those, exclusive of the authors, who made significant contributions to the work described in this report.

$\underline{\text { PLANNING AND ANALYSIS }}$

M. L. Batch

D. Erdman

A. J. Friedland

P. M. Harrigan

A. E. Klickman

C. C. Scott
APDA

PRDC

APDA

PRDC

APDA

APDA

\section{TESTING}

E. Halas

APDA 
Tests were conducted on the Enrico Fermi reactor to determine performance under control of the automatic loading programmer. Automatic approach to power was accomplished at power levels of 13.3, 20, and $110 \mathrm{Mwt}$. In each case, an automatic decrease in power was accomplished after the desired power level was reached. In the test at $13.3 \mathrm{Mwt}$, two coolant circuits were in use, while in the tests at 20 and $110 \mathrm{Mwt}$, three coolant circuits were in operation. The basic test procedure began after the reactor had been brought to approximately 10 per cent of full power under manual control. The initial steps were to switch to automatic control, set the loading programmer temperature demand corresponding to the desired power, and switch to programmer-controlled operation. Feedwater flow was manual during the test. Reactor behavior was monitored during the subsequent power increase and decrease.

Test results have provided data on rates of change of power and temperature, as well as general performance characteristics of the reactor and associated heat transport system. These verify smooth power increase and decrease. The results demonstrate that the plant parameters are within established limits under automatic approach to power and on run-down, and that operation at the programmed power level is stable.

Under programmed operation,the maximum rate of change of powerwas $1.2 \mathrm{Mwt} / \mathrm{min}$, while that of temperature was $1.3 \mathrm{~F} / \mathrm{min}$ for the reactor outlet sodium. The maximum rate of change of core outlet sodium temperature was about $2.4 \mathrm{~F} / \mathrm{min}$. Though the parameter responses exhibited a perceptible oscillatory characteristic on run-up and run-down in the 13.3- and 20-Mwt tests, the responses in the 110-Mwt test had no oscillation and exhibited, instead, a highly stable response for the plant. 


\section{PURPOSE OF TESTS}

The purpose of the tests was to demonstrate that the automatic loading programmer, operating in conjunction with the reactor automatic control system, will increase and decrease the reactor power level with temperature rates not exceeding $100 \mathrm{~F} / \mathrm{hr}$, and to confirm that performance of the plant was satisfactory over the power ranges of the tests. 
$\bullet$

• 


\section{GENERAL DESCRIPTION OF THE ENRICO FERMI REACTOR ${ }^{1}$}

The Fermi reactor and its associated structures are shown in perspective in Fig. 1. The reactor is contained in a stainless steel reactor vessel sealed at the top by a rotating shield plug which supports the control mechanism, the fuel subassembly holddown mechanism, and the fuel subassembly handling mechanism. The reactor vessel is surrounded by borated and plain graphite neutron shielding material which is contained inside the primary shield tank. The reactor is of the fast-breeder type, cooled by sodium and operated at essentially atmospheric pressure. The maximum reactor power obtainable with the first core loading (core A) is $200 \mathrm{Mwt}$.

The core and blanket are located in the lower reactor vessel and consist of 2.65-in. -square subassemblies containing the fuel pins and blanket rods. The core and blanket subassemblies are arranged to approximate a cylinder about $80 \mathrm{in.}$ in diameter and $70 \mathrm{in.} \mathrm{high.} \mathrm{The} \mathrm{core,} \mathrm{which}$ is contained in the central portion of the core subassemblies, approximates a right cylinder $31 \mathrm{in.}$ in diameter and $31 \mathrm{in.} \mathrm{high;} \mathrm{it} \mathrm{is} \mathrm{axially} \mathrm{and} \mathrm{radially}$ surrounded by the breeder blankets. The fuel in the first core loading consists of zirconium-clad pins containing U-10 w/o molybdenum alloy with the uranium enriched to $25.6 \mathrm{w} / \circ \mathrm{U}-235$. The blanket is depleted $\mathrm{U}-3 \mathrm{w} / \mathrm{o}$ molybdenum alloy.

The reactor cross section, shown in Fig. 2, indicates the placement of individual components within the lower reactor vessel. There is a total of 149 central lattice positions used for core and inner radial blanket subas semblies and operating control and safety rods, all of which are supplied with sodium coolant flowing upwards from a plenum which is fed directly from the discharge of the primary sodium pumps. Owing to the large pressure drop across this region, through which flows about 90 per cent of the total sodium, the subassemblies located in it require downward mechanical restraint in addition to their own weights, to prevent ejection from the lower support plates. This restaint is supplied by the holddown mechanism.

The lattice positions surrounding the inner radial blanket comprise the outer radial blanket area and, when filled with outer radial blanket subassemblies, form an annular region whose top and bottom are at the same elevation as the top and bottom of the inner radial blanket. Surrounding the outer radial blanket are lattice positions used for steel subassemblies which provide thermal and neutron shielding. The lattice positions occupied by outer radial blanket and shielding subassemblies are supplied with sodium coolant from a low-pressure plenum which is fed from the primary sodium pumps through throttle valves. The force produced by the pressure drop acting on these subassemblies is less than their weight so that no holddown is required. 


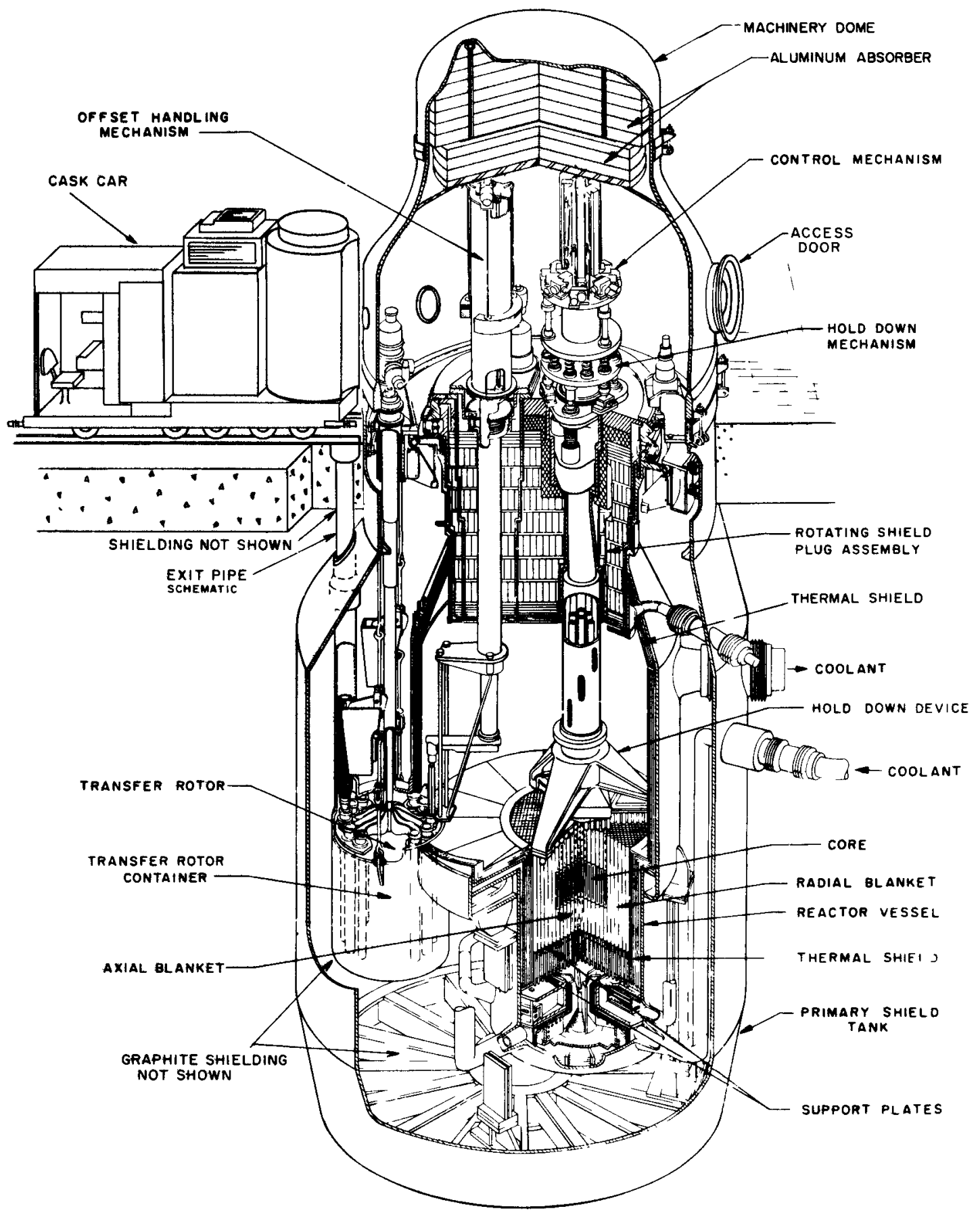

002768

FIG. I PERSPECTIVE VIEW OF REACTOR 


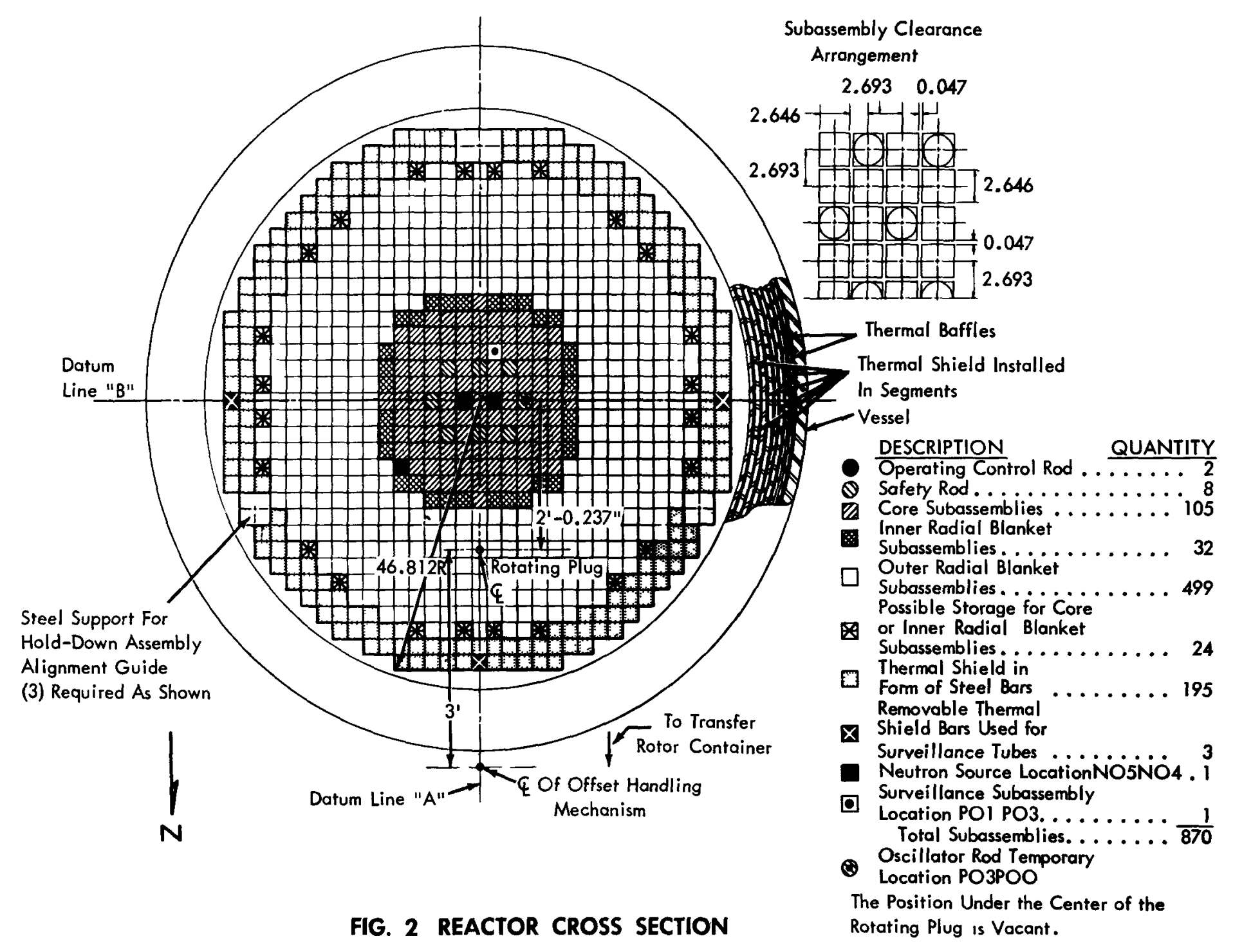


Control of the reactor is accomplished by two operating control rods and seven safety rods. All the rods are of the poison type, containing boron carbide $\left(\mathrm{B}_{4} \mathrm{C}\right)$ in which the boron is enriched in B-10. One operating control rod is for regulating purposes and the other is for shimming; they have maximum reactivity insertion rates of about $2 / 3 \mathrm{cent} / \mathrm{sec}$ and $1 \mathrm{cent} / \mathrm{min}$, res pectively. Together, they provide a total of 92 cents of reactivity to compensate for temperature override, burnup, and operating flexibility. The seven safety rods, which are located around the core about 7 in. from its vertical centerline, provide a shutdown reactivity of over 8 dollars. During reactor operation, the safety rods are poised just above the axial blanket section of the core so that they can be rapidly inserted into the core if necessary for scram, or driven in at the rate of $10 \mathrm{ft} / \mathrm{min}$. The safety rods provide the shutdown during refueling operations.

The plant is designed for manual approach to criticality and low-power operation, and for either manual or automatic plant loading in the power range. Plant loading is determined by the reactor, not by system demand.

Heat produced in the reactor is removed by three primary coolant loops contained within the reactor building. Flow in the primary coolant system is upwards through the core and blanket into a large plenum region designated the upper reactor pool. Because the primary sodium is radioactive, its heat is transferred by three intermediate heat exchangers within the reactor building to three nonradioactive secondary sodium loops, and, finally, to three once-through steam generators in the steam generator building. Here steam is produced to operate the turbine in the adjacent turbine house. 


\section{EXPERIMENTAL APPARATUS AND EQUIPMENT}

The understanding of reactor control and overall system operation requires knowledge of plant instrumentation used to monitor the principal plant parameters. This section contains information on the detectors of main interest in this test, their main functions, and a brief account of the signal-handling circuitry employed to obtain the signal recording. The signal parameters recorded during this test are listed in Table 1.

\section{A. DETECTORS}

Brief descriptions of the detectors of concern in this test and their physical locations and plant functions are presented below. Locations of the temperature detectors in the heat transport system are illustrated schematically in Fig. 3.

\section{Reactor Outlet Temperature (TE-201)}

The temperature detector used to sense reactor outlet temperature is a resistance thermometer which has a time constant of $6.07 \mathrm{sec}$. One such detector is provided in each of the three 30 -in. reactor outlet pipes; mounting is in a well-type arrangement. These detectors are given the designation $\mathrm{TE}-201$, followed by a number representing the coolant circuit number. The TE-201 detectors are used in the reactor control system, reactor setback system, and the feedwater flow control system. To avoid impairing the normal control functions of the detector, connection of the strip-chart recorder was made at the demodulator of the RTD signal amplifier.

The RTD (resistance temperature detector) comprises one of the elements of a bridge circuit, the output of which is a d-c voltage proportional to $R T D$ resistance. The $d-c$ voltage is modulated at a rate of 10 kcps and amplified by an a-c amplifier. The amplified a-c signal is converted back to $d-c$ by the demodulator. The demodulator provided a low source impedance and thereby prevented introduction of reading errors due to loading by the input circuit of the recorder.

\section{Core Outlet Temperature (TE-115)}

Fifty-five thermocouples are provided in the Fermi reactor to monitor the coolant outlet temperatures of the core subassemblies. These thermocouples were manufactured with junctions grounded to the sheath (contact only, not welded) for fast response, which is about $1 \mathrm{sec}$. The junctions in several of the TE-115 thermocouples have become ungrounded 
TABLE 1 - RECORDER SCALE SPANS USED DURING TEST OF AUTOMATIC APPROACH TO POWER AT $13.3 \mathrm{Mwt}, 20 \mathrm{Mwt}, 110 \mathrm{Mwt}$

$\begin{array}{r}\text { Paramet } \\ \text { Detecto }\end{array}$
TE-1 15-9
TE-201-1
TE-201-2
TE-201-3
TE-209-2
TE-209-3
TE-308-2
TE-308-3
TE-301-1C
TE-301-2D2
TE-301-3C
TE-601-2
TE-601-3
T $-T_{A}$

Regulator Rod:

Position

Velocity

Velocity Demand

Shim Rod Position

Neutron Flux:

Electrometer

Rate of Change

Feedwater Flow
-1 to 8.5 in.

+11 in. $/ \mathrm{min}$

$\pm 15 \mathrm{in.} / \mathrm{min}$

NR
$0-1 \times 10^{-5}$ amp $\pm 5 \mathrm{Mwt} / \mathrm{min}$

NR

Recorder Span

$\begin{array}{cc}20 \mathrm{Mwt} & 110 \mathrm{Mwt} \\ 500-600 \mathrm{~F} & 500-800 \mathrm{~F} \\ \mathrm{NR} & \mathrm{NR} \\ \mathrm{NR} & 500-700 \mathrm{~F} \\ 500-550 \mathrm{~F} & \mathrm{NR} \\ \mathrm{NR} & 500-600 \mathrm{~F} \\ 500-550 \mathrm{NR} & \mathrm{NR} \\ \mathrm{NR} & \mathrm{NR} \\ 500-550 \mathrm{~F} & \mathrm{NR} \\ 500-550 \mathrm{~F} & \mathrm{~N} \\ \mathrm{NR} & \mathrm{NR} \\ \mathrm{NR} & \pm 5 \mathrm{~F} \\ \mathrm{NR} & \end{array}$

$$
\begin{gathered}
-1 \text { to } 8.5 \mathrm{in} . \\
\pm 11 \mathrm{in.} / \mathrm{min} \\
\pm 15 \mathrm{in.} / \mathrm{min} \\
\mathrm{NR}
\end{gathered}
$$

$0-1 \times 10^{-5}$ amp $+5 \mathrm{Mwt} / \mathrm{min}$

NR
- 1 in. to $19 \mathrm{in.}$ NR NR

- 1 in. to $19 \mathrm{in.}$

$0-0.5 \times 10^{-4} \mathrm{amp}$ NR

* Not recorded 


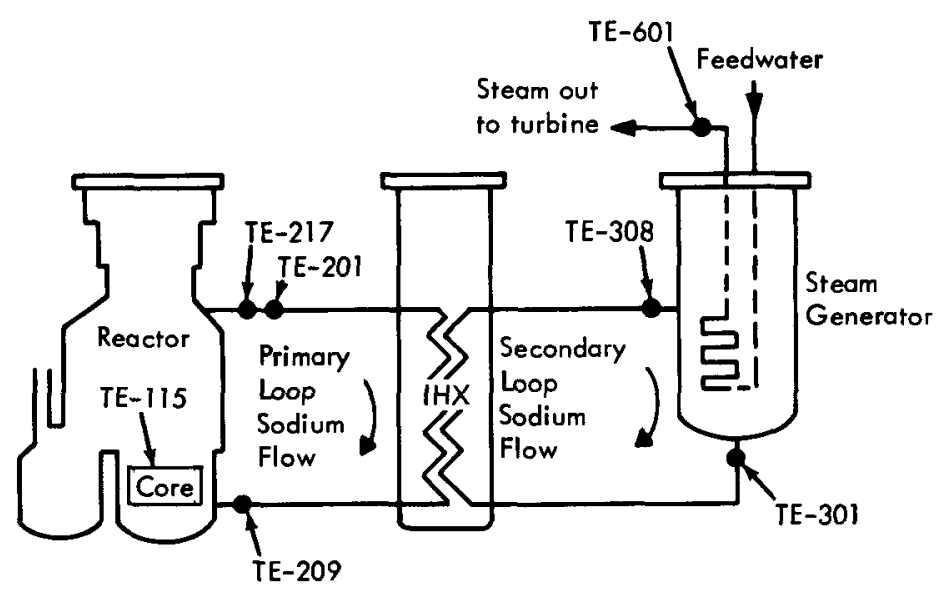

003068

FIG. 3 SCHEMATIC DIAGRAM OF TEMPERATURE DETECTOR LOCATIONS IN THE FERMI REACTOR HEAT TRANSPORT SYSTEM 
in the course of normal operations because of a difference of coefficients of linear expansion of the sheath and conductor materials. The response of an ungrounded thermocouple could be of the order of $5 \mathrm{sec}$. The mounting inside the holddown finger is such that the thermocouple is close to the conical cavity which seats on the subassembly handling head. These sensors are given the designation of TE-115.

The TE-115 detectors are used in the reactor safety system and core temperature automatic scanner and alarm. Core outlet temperature signals from four TE-115 thermocouples control bistable multivibrators which feed the 2-out-of-4 AND gate logic circuit in the safety system. The AND gate is connected in a manner that two "unsafe" signals must be present before an "unsafe" signal is applied to the scram logic OR gates, scramming the reactor.

\section{Steam Generator Sodium Inlet Temperature (TE-308)}

A resistance-type temperature detector (RTD) mounted in a thermowell in each 18-in. pipe of the inlet piping system to the steam generator is used to monitor the steam generator sodium inlet temperature. The detector is located in the region of the " $T$ " connection in the 18-in. pipe which splits the steam generator inlet sodium flow to the two 12 -in. inlet nozzles of the steam generator. The time constant of this sensor is about $25 \mathrm{sec}$. The detectors are given the designation of TE-308.

The TE-308 detectors have no control functions, but provide information to an indicator in the control room. A pneumatic retransmitter is used to drive the indicator. To obtain a signal from the RTD, a separate bridge circuit was provided. A suitable scale factor was set up for the recorder by means of the recorder gain adjustment.

\section{Steam Generator Sodium Outlet Temperature (TE-301)}

The steam generator sodium outlet temperature is used as one of the basic signals in the feedwater control system to establish a demand signal for feedwater flow. Emergency feedwater flow also is controlled by the steam generator sodium outlet temperature. The detectors originally provided in the steam generator sodium outlet piping to monitor the temperature were resistance thermometers located about $1-1 / 2 \mathrm{ft}$ from the bottom of the steam generator vessel. Response of the detectors was estimated to be $2.5 \mathrm{sec}$. Early in the reactor test program it was observed that flowchanneling of relatively hot sodium along the walls of the steam generator sodium outlet piping was producing erratic and high readings of these detectors because of poor mixing at this point. To obtain a better temperature signal, thermocouples were installed in thermowells about 75 equivalent pipe diameters downstream from the original detector locations. The response of the basic thermocouple is about $1.5 \mathrm{sec}$. 


\section{Reactor Inlet Temperature (TE-209)}

The reactor inlet temperature detector, designated TE-209, is located at the bottom of a standpipe in the 6-in. pipe leading to the radial blanket sodium inlet plenum. The detector is a resistance thermometer identical to the TE-201 detector which has a time constant of 6.07 sec.

\section{Water-Steam Temperature (TE-601)}

Resistance-type temperature detectors are mounted in a thermowell in the water-steam outlet pipe of each steam generator. These detectors are designated TE-601 and they are the same type as TE-308 with a time constant of $25 \mathrm{sec}$. The water-steam temperature signals are used in the reactor program controller and the plant recorders and indicators.

\section{Neutron Flux}

The neutron flux detector used for measuring and monitoring reactor power during the tests was a B-10-lined, compensated ion chamber (Reuter-Stokes, Inc.); it was designated NE-116. This detector was installed in neutron-counter tube No. 5, located as shown in Fig. 4 (see also Ref. 4). Output of the ion chamber is read on an electrometer (Keithley Instruments, Inc. Model 415) located in the control room. A coaxial cable approximately $250 \mathrm{ft}$ long interconnects the ion chamber and the electrometer. The time constant of the neutron flux measuring instrumentation is of the order of 10 milliseconds.

\section{B. SIGNAL CONDITIONING CIRCUITS AND ADJUNCTIVE APPARATUS}

Since a readily available signal was not existent in some cases to record a plant parameter, a special bridge circuit had to be provided for some RTD's to enable their operation and calibration; the basic circuit is shown in Fig. 5. Some detectors required special care to prevent upsetting the normal operation of the circuit by recorder loading or by an accidental short circuit which could impair or otherwise alter the detector output signal. Since the outputs of the TE-201 detectors have important control functions, the output of each TE-20l detector recorded was taken at the output of the demodulator where the circuit impedance was low. An available spare TE-301 detector already in the system was placed into use for the tests. The TE-209 detector used was temporarily diverted from its normal function in the safety rod withdrawal interlock circuit. A signal from the TE-60l detector was obtained from the retransmitting slidewire of the plant recorder into which the detector normally works. The TE-301 signal was obtained at the output of a load-isolating (low output impedance) amplifier.

Figures $6 \mathrm{a}, 6 \mathrm{~b}$ and $6 \mathrm{c}$ show, in block diagram form, the circuits of the resistance thermometer detectors, and Fig. 6d shows the circuit for the TE-301 thermocouples. 


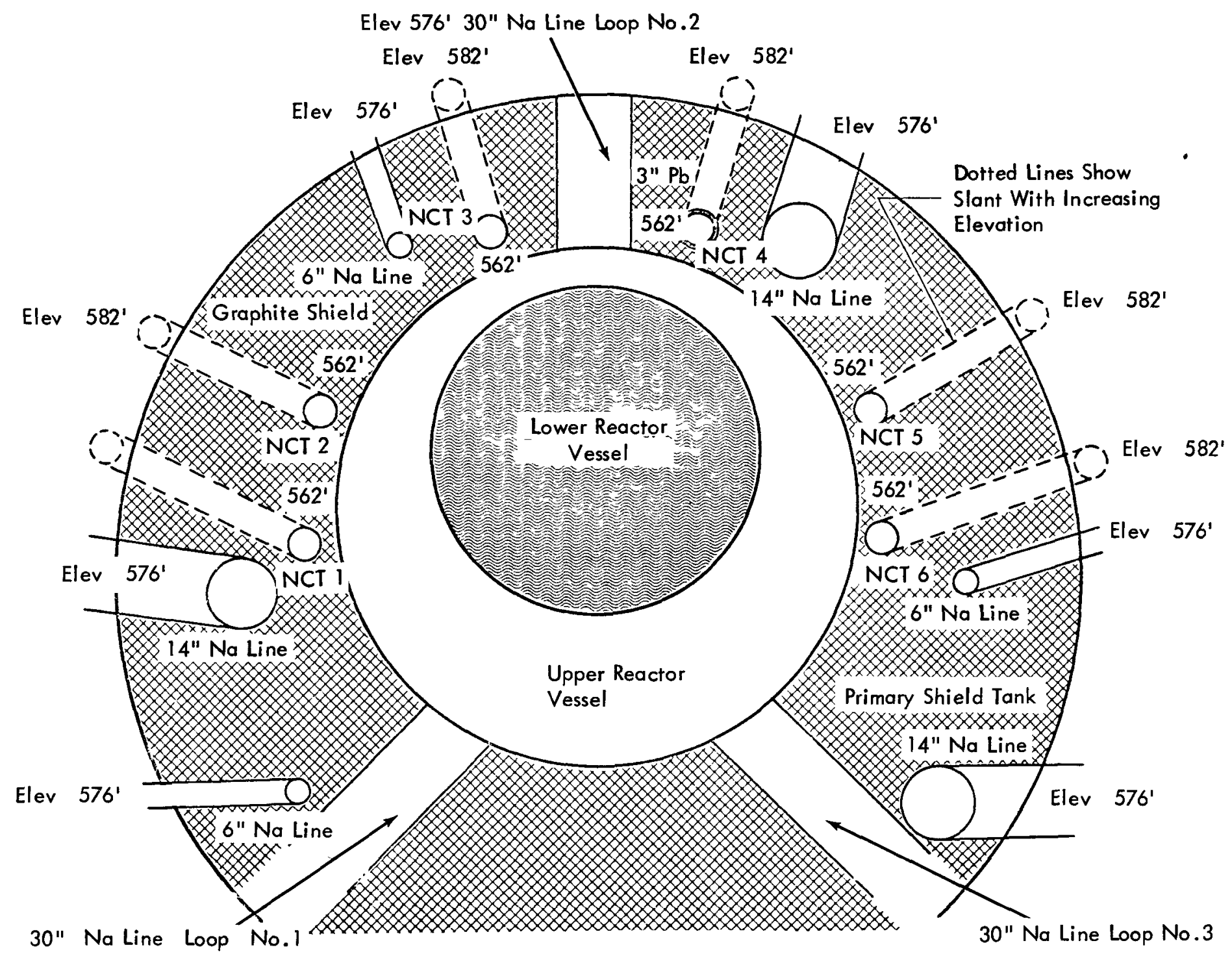




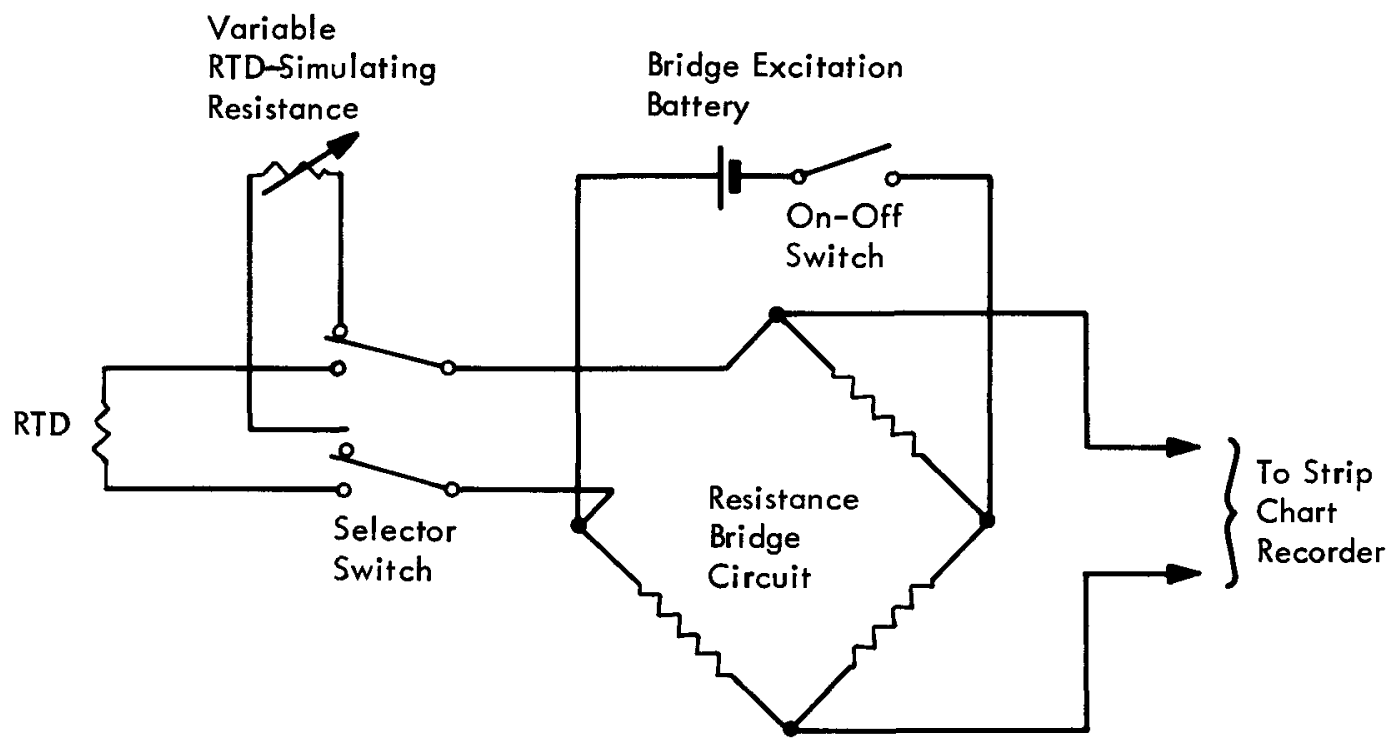



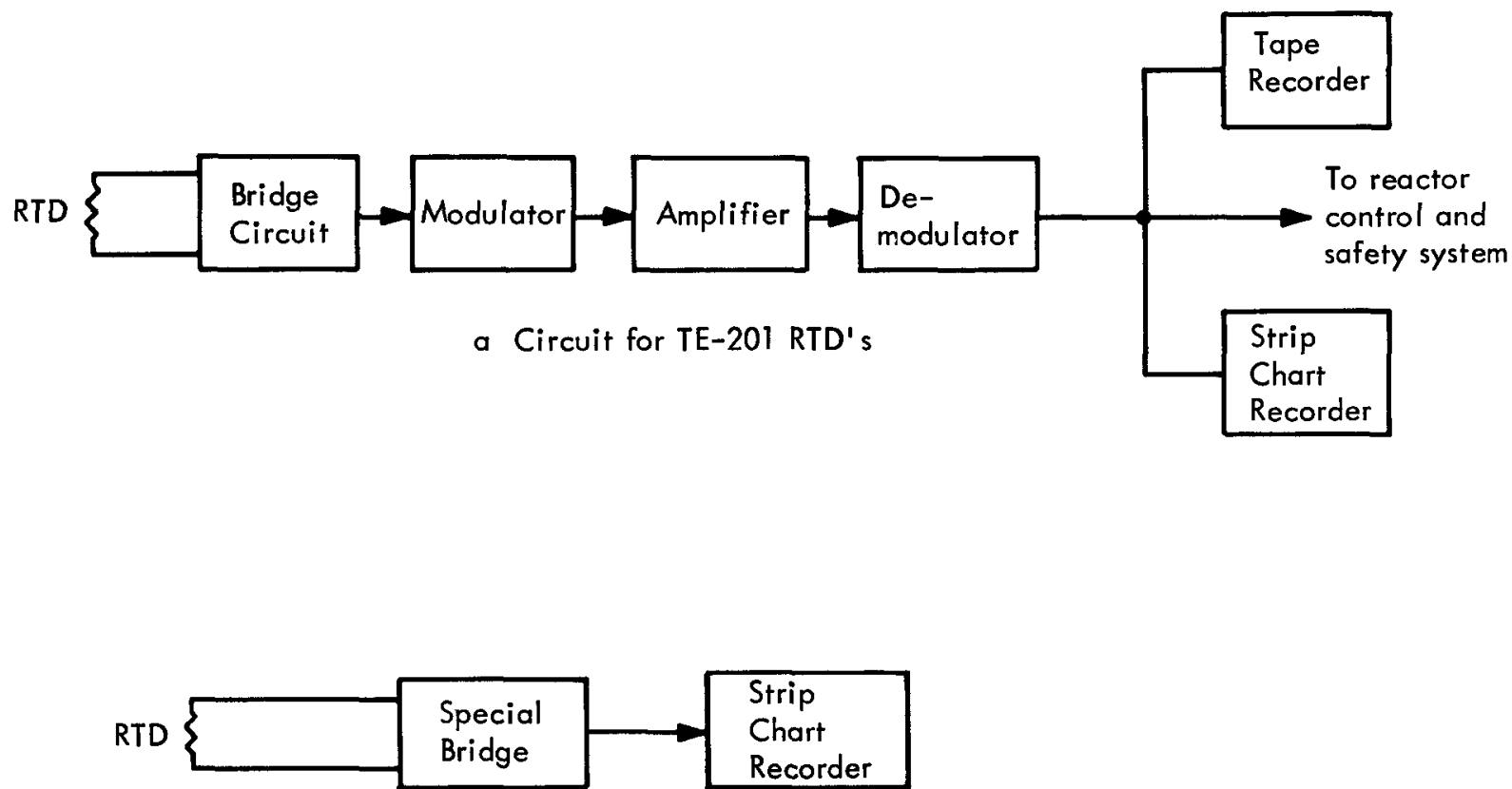

b Circuit for TE-209 and TE-308 RTD's
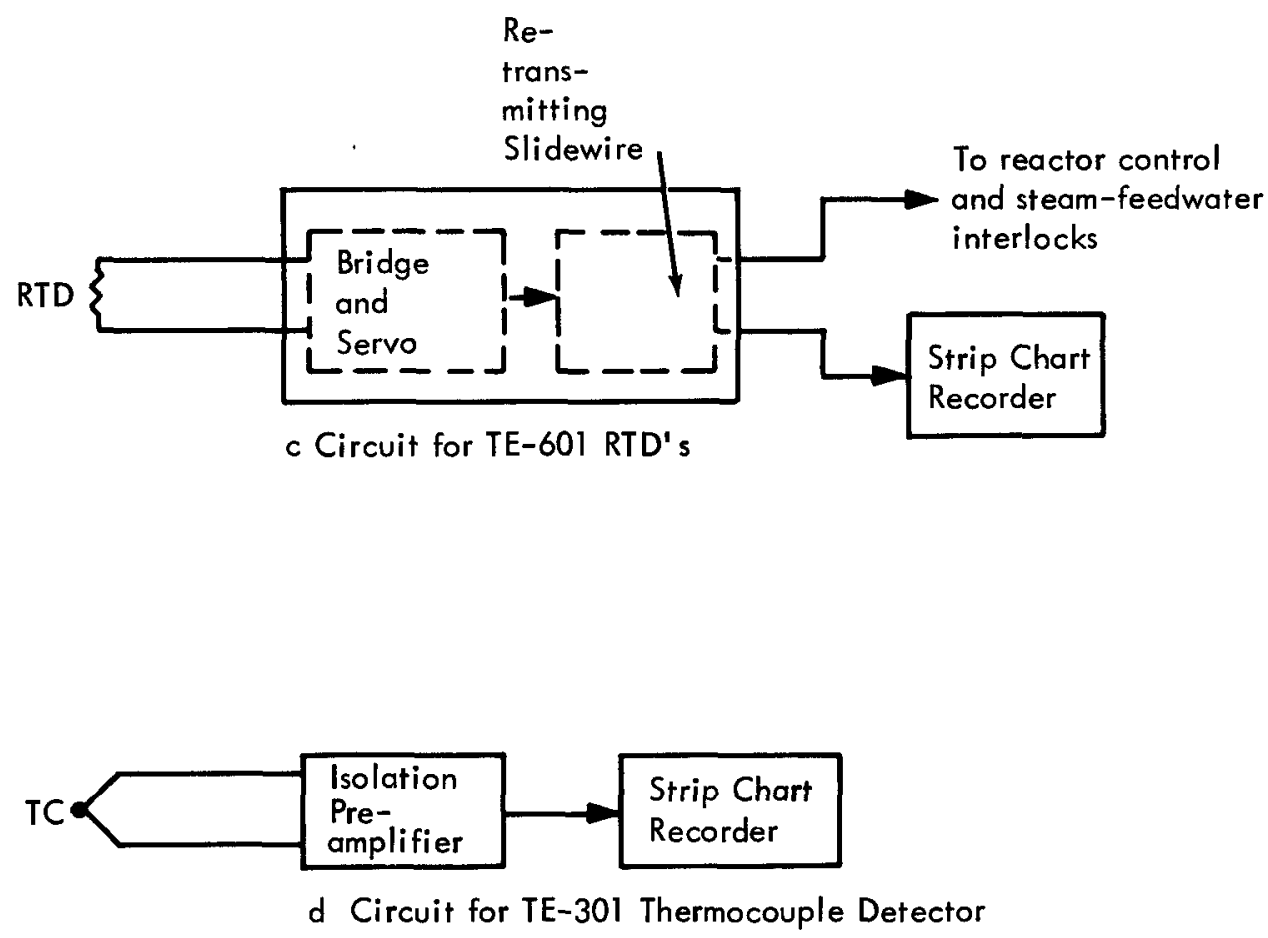
Adjunctive apparatus and equipment employed in this test consisted of the following major items:

- Eight-channel strip-chart recorders having a minimum response of $50 \mathrm{cps}$, and containing suppression and span calibrating provisions - used for recording the system parameters such as temperatures, regulator rod position, and neutron flux

- Millivolt box - used for simulating the output of a thermocouple

- Four-arm resistance bridge circuits, equipped with a battery power supply for excitation of the bridge - used for simulating an RTD during recorder calibration, and to provide the required bridge circuitry for operation of RTD's TE-209 and TE-308 apart from their respective plant recorders.

\section{AUTOMATIC LOADING PROGRAMMER}

The automatic loading programmer functions to increase or decrease reactor power in accordance with an established schedule of power versus time. The schedule is based on specific conditions of primary and secondary sodium flow, number of coolant circuits, feedwater temperature, steam generator pressure, and IHX and steam generator efficiency, and limits the rate of $\mathrm{rise}$ of the system temperature to a specific maximum value. When operating on two coolant circuits, the feedwater flow and power are at $2 / 3$ of their three-circuit values, but no change is made for the temperature scale. A schedule for temperature and power histories for 200-Mwt operation is given in Fig. 7. The output of the automatic loading programmer is an instantaneous setpoint temperature signal fed to the input to the reactor automatic control system. The ultimate temperature setpoint is that to which the automatic loading programmer brings the reactor for steadystate operation. The schedule of power-time history for the Enrico Fermi Atomic Power Plant requires that the maximum rate of change of temperature in any coolant system be held to $100 \mathrm{~F} / \mathrm{hr}$ or less. Two programmer speeds, slow rate and fast rate, are employed for this. The fast rate is used on power run-up to the start of superheat conditions in the steam generators. As the water in the steam generators forms superheat, the steam outlet temperature rapidly rises toward the temperature of the inlet sodium. To retain the rate of rise of temperature at $100 \mathrm{~F} / \mathrm{hr}$, the programmer drops the temperature setpoint rise to the slow rate. After steam conditions in the steam generator stabilize, the programmer resumes the fast rate and continues it until the outlet sodium temperature of the reactor reaches the ultimate setpoint level. 


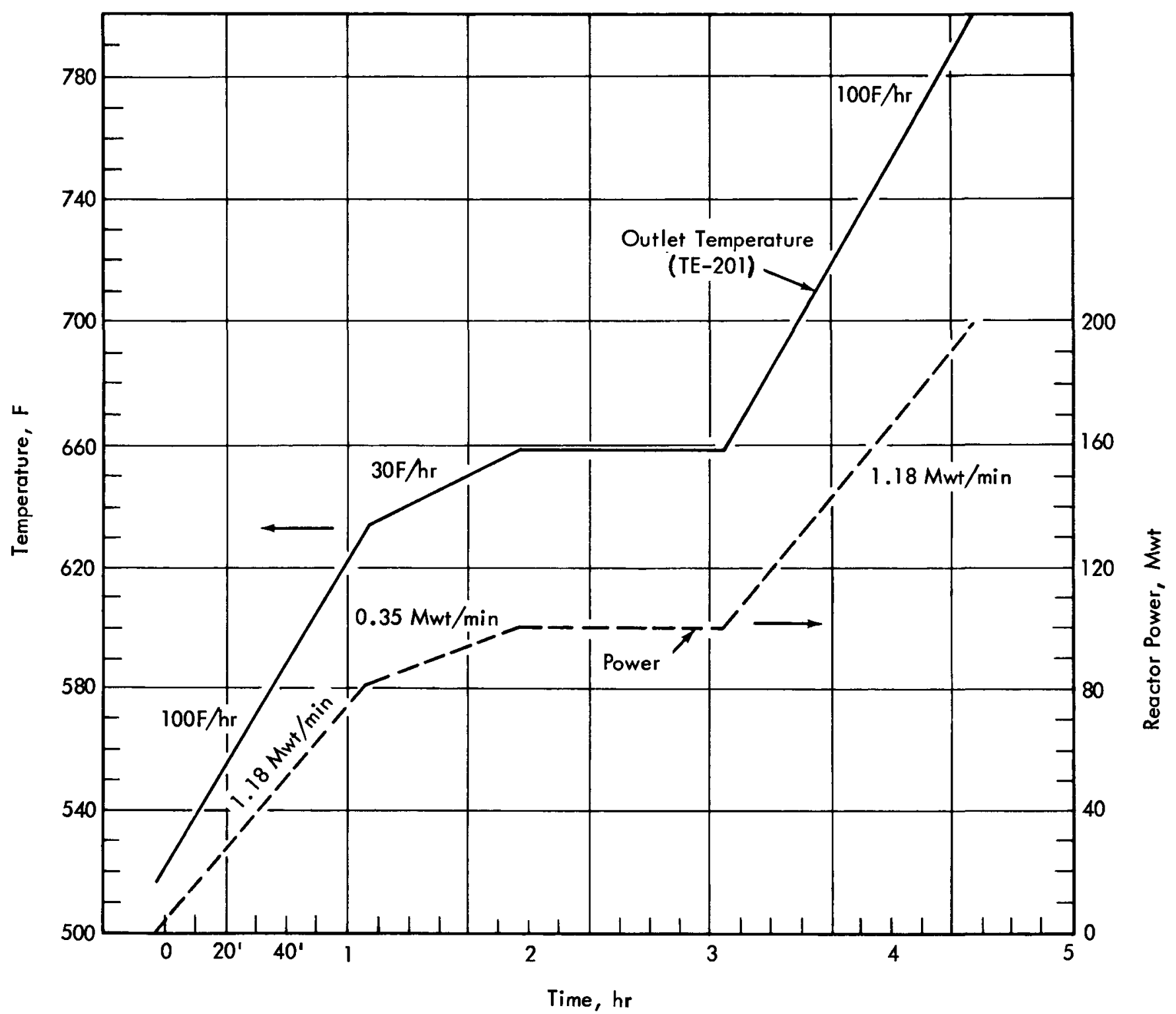

FIG. 7 SCHEDULE OF TEMPERATURE AND POWER VERSUS TIME 


\section{EXPERIMENTAL PROCEDURE AND PLANT CONDITIONS}

The test, following a prescribed procedure ${ }^{2}$, began after the reactor was brought to a power level of approximately $8 \mathrm{Mwt}$ by manual control. The initial steps were to switch the reactor to automatic control, place the automatic loading programmer setpoint to the desired temperature, and switch to programmer-controlled operation. Feedwater control during each of the test runs was manual. The reactor behavior then was monitored until the desired reactor power was reached. After a brief waiting period, the automatic loading programmer was reset, to force the reactor power to decrease to its initial value. In the 110-Mwt test, the steam generator outlet steam pressure was held constant throughout the test, i.e., pressure ramp down was not performed. The feedwater temperature was $340 \mathrm{~F}$. In the 13.3-Mwt and 20-Mwt tests, all plant conditions were normal and no special limitations had to be imposed either for the control system or the plant protection system. In the 110-Mwt test,the only special condition imposed was that of defeating the interlock which prevents a programmed reduction in power when the main steam line nonreturn valves (FSV-609) are open. This was required for flexibility to enable completion of the power decrease portion of the test. The interlock defeat was permissible inasmuch as turbine operation was not required in the test. 


\section{EXPERIMENTAL RESULTS AND ANALYSIS}

The test at 13.3 Mwt was performed with the plant operating on two coolant circuits, Nos. 1 and 3, while the 20-Mwt and 110-Mwt tests were conducted on three coolant circuits. The circuit flows are listed in Table 2.

\section{A. RESULTS}

Presented below are descriptions of the parameter responses recorded during the tests at 13.3,20, and $110 \mathrm{Mwt}$. The reactor response during the programmed power run-up and run-down, including duration of the change and hold at maximum power, will be found in the discussion of the neutron flux recording. Since the responses of the other parameters are directly related to reactor power, and since transport lags and time constants have been presented in another report ${ }^{3}$, only a brief description need be given for the plant parameters.

\section{13.3-Mwt Test}

This test was conducted with plant operation on two coolant circuits. The inoperative circuit was No. 2 .

\section{a. Neutron Flux}

Before start of the programmed power increase to the nominal test level of 13.3 Mwt, the reactor was manually brought to $10.6 \mathrm{Mwt}$ (an electrometer reading of $0.37 \times 10^{-5} \mathrm{amp}$ ). The demand temperature was set, and the programmer advanced the power level to $13.8 \mathrm{Mwt}$ in about 310 sec with a smooth rise. After reaching $13.8 \mathrm{Mwt}\left(0.47 \times 10^{-5} \mathrm{amp}\right)$, the power dipped to $11.6 \mathrm{Mwt}\left(0.4 \times 10^{-5} \mathrm{amp}\right)$ and leveled-off at $12.4 \mathrm{Mwt}$ $\left(0.42 \times 10^{-5} \mathrm{amp}\right)$ in about $20 \mathrm{~min}$ after start of the programmed increase. The power was left at this level for about $15 \mathrm{~min}$ and the demand temperature was set for run-down to essentially the starting power level. The power dipped to $2.9 \mathrm{Mwt}\left(0.12 \times 10^{-5} \mathrm{amp}\right)$ in about $400 \mathrm{sec}$, then increased to the level-off value of $8.5 \mathrm{Mwt}\left(0.3 \times 10^{-5} \mathrm{amp}\right)$ about $20 \mathrm{~min}$ after start of the programmed power decrease. The maximum rate of change of power measured from the charts during the test was approximately $1.0 \mathrm{Mwt} / \mathrm{min}$. Start of the power rise occurred simultaneously with the setting of the command for power increase.

\section{b. Neutron Flux Rate-of-Change}

The indicated neutron signal of flux rate of change rose to a maximum of about $+1.0 \mathrm{Mwt} / \mathrm{min}$ during power $\mathrm{run}-\mathrm{up}$, and a maximum of 
TABLE 2 - SODIUM FLOW RATES IN THE PRIMARY AND SECONDARY HEAT TRANSPORT LOOPS DURING THE TEST ON AUTOMATIC APPROACH TO POWER

$\underline{\text { Primary Loop Sodium Flow, } 1 \mathrm{~b} / \mathrm{hr} \times 10^{6}}$

Circuit No. 1 14-in. Pipe 6-in. Pipe

13. $3 \mathrm{Mwt}$

$20 \mathrm{Mwt}$

$110 \mathrm{Mwt}$

నั

0.419

2. 70

Circuit No. 2 14-in. Pipe 6-in. Pipe

$-0.45$

2.65

0.24

0.41

0.419

2. 75

18-in. Secondary Loop Sodium Flow, 1b/hr $\times 10^{6}$

\section{Circuit No. 1}

13. $3 \mathrm{Mwt}$

$20 \mathrm{Mwt}$

$110 \mathrm{Mwt}$

$$
3.00
$$

2.93

3. 15
Circuit No. 2

2.93

3.1
Circuit No. 3

14-in. Pipe 6-in. Pipe

2. 40

0.29

2. 50

0.395

2. 80

0.420
Circuit No. 3

3.05

2.93

3.2 
-1.0 Mwt/min during power run-down, which is satisfactorily consistent with the measured maximum rate of change of power. The rate-of-change signal contained sharp noise pulses having a repetition rate of $120 \mathrm{sec}$ and peak level of about $2 \mathrm{Mwt} / \mathrm{min}$, with a duration estimated to be less than 1 sec.

\section{c. Core Outlet Temperature (TE-115)}

The reading of TE-115-9 was $524 \mathrm{~F}$ before power run-up. On power run-up, the temperature rose to $559 \mathrm{~F}$ in about $320 \mathrm{sec}$. The maximum rate of rise of temperature was about $2.5 \mathrm{~F} / \mathrm{min}$. After reaching $559 \mathrm{~F}$, the temperature dipped to $553 \mathrm{~F}$ and rose to $555 \mathrm{~F}$, at which point it leveled off. On power run-down, TE-115-9 dipped to $528 \mathrm{~F}$ and rose to $539 \mathrm{~F}$ where it leveled off in $900 \mathrm{sec}$ after start of the run-down. The maximum rate of decay of temperature during run-down was $2.5 \mathrm{~F} / \mathrm{min}$.

\section{d. Reactor Outlet Temperature (TE-201)}

The reading of TE-201-1 was $535 \mathrm{~F}$ up to the start of the test. With run-up in power, the temperature rose to a peak of $540 \mathrm{~F}, 480 \mathrm{sec}$ after start of the power increase, where it remained constant until the programmed decrease in power. On run-down of power, the temperature dipped to $525 \mathrm{~F}$, then smoothly rose to the level-off value of $529 \mathrm{~F}$ about 20 min after start of the run-down. The maximum rate of change of temperature measured was $0.8 \mathrm{~F} / \mathrm{min}$, or $48 \mathrm{~F} / \mathrm{hr}$.

Up to the start of the test, TE-201-3 read 540F. On power run-up, the temperature rose to a peak of $547 \mathrm{~F}$ about $450 \mathrm{sec}$ after start of the run-up, then dropped to $545 \mathrm{~F}$ after $20 \mathrm{~min}$, where it remained until start of the power run-down. On run-down, TE-201-3 dipped to $530 \mathrm{~F}$, and then rose to a level-off value somewhere above $535 \mathrm{~F}$ beyond $20 \mathrm{~min}$, at which point the recording ended. The maximum rate of change of temperature observed in the recording of TE-201-1 was $1.5 \mathrm{~F} / \mathrm{min}$, or $90 \mathrm{~F} / \mathrm{hr}$.

\section{e. Steam Generator Sodium Inlet Temperature (TE-308)}

The reading of TE-308-3 up to the start of the programmed power run-up was $526 \mathrm{~F}$. With the run-up in power the temperature rose to $531 \mathrm{~F}$ in about $550 \mathrm{sec}$, then decreased to $529 \mathrm{~F}$ at which point it held constant until start of the power decrease. On decrease of power, TE-308-3 dipped to $517 \mathrm{~F}$, then rose to $525 \mathrm{~F}$ where it leveled off beyond $20 \mathrm{~min}$, where the recording ended. The maximum rate of change of temperature measured approximately $0.6 \mathrm{~F} / \mathrm{min}$. 


\section{f. Reactor Inlet Sodium Temperature (TE-209)}

Before the power increase, TE-209-3 read $527 \mathrm{~F}$. On run-up of power, the temperature rose to $530 \mathrm{~F}$ about $600 \mathrm{sec}$ after start of the power increase. On run-down, TE-209-3 dipped to about $522 \mathrm{~F}$, then rose to about $526 \mathrm{~F}$ where it leveled off somewhere beyond the $20-$ min point at which the recording ended.

\section{g. Steam Generator Sodium Outlet Temperature (TE-301)}

Before power run-up, the reading of $\mathrm{TE}-301-3 \mathrm{C}$ was $534 \mathrm{~F}$. On run-up, the temperature rose to a peak of $537 \mathrm{~F}$ after about $600 \mathrm{sec}$, then dropped off to $536 \mathrm{~F}$ where it held until the power run-down. On run-down, the temperature dropped to $529 \mathrm{~F}$, then rose to the level-off value of $533 \mathrm{~F}$ beyond the $20-$ min point where the recording ended.

\section{h. Steam Generator Steam and Water Temperature (TE-601)}

Before power run-up, the reading of TE-601-3 was approximately $500 \mathrm{~F}$. On run-up of power, the temperature rose to $510 \mathrm{~F}$ about $500 \mathrm{sec}$ after start of the power rise. On run-down, the reading of $T E-601-3$ decreased to the level-off value of $500 \mathrm{~F}$. The recorded trace contained a band of random temperature fluctuations having a peak-to-peak amplitude of about $5 \mathrm{~F}$.

\section{i. Regulator Rod Position, Velocity, and Velocity Demand}

A satisfactory recording of the regulator rod position was not obtained during the test because of difficulty with the recorder. The velocity and velocity demand signals reached maximum levels corresponding to $0.30 \mathrm{in} / \mathrm{min}$.

$$
\text { j. Temperature } \operatorname{Error}\left(\mathrm{T}_{\mathrm{I}}-\mathrm{T}_{\mathrm{A}}\right)
$$

This parameter represents the temperature difference between the actual temperature $\left(\mathrm{T}_{\mathrm{A}}\right)$ as read by $\mathrm{TE}-201$ and the temperature signal from the programmer $\left(\mathrm{T}_{\mathrm{I}}\right)$ supplied to the reactor automatic control circuit. The temperature demand was set to $535 \mathrm{~F}$, and the error signal from the programmer rose to a maximum of about $+4 \mathrm{~F}$ in about $120 \mathrm{sec}$, and diminished to zero as the reactor outlet temperature reached the set level. In power run-down, the error signal increased to $-4 \mathrm{~F}$, then decreased to zero as the reactor outlet temperature leveled off.

\section{20-Mwt Test}

This test was conducted with the plant operating on three coolant circuits . 


\section{a. Neutron Flux}

Before start of the programmed power increase to the nominal 20-Mwt test level, the reactor was manually brought to $8.5 \mathrm{Mwt}\left(0.3 \times 10^{-5}\right.$ amp). The demand temperature was set and the programmer advanced the power level to $21 \mathrm{Mwt}\left(0.7 \times 10^{-5} \mathrm{amp}\right)$ in about $650 \mathrm{sec}$. Start of the power rise occurred $70 \mathrm{sec}$ after setting of the command for power increase. The maximum rate of change of power during the run-up was $1.2 \mathrm{Mwt} / \mathrm{min}$ as measured from the power charts. The power was held at $21 \mathrm{Mwt}$ approximately $10 \mathrm{~min}$. On run-down, the reactor was brought back to $8.5 \mathrm{Mwt}$ in about $620 \mathrm{sec}$. The maximum rate of change of power on run-down was 1. $2 \mathrm{Mwt} / \mathrm{min}$.

\section{b. Neutron Flux Rate-of-Change}

The rate of change of neutron flux, as recorded, had a maximum level of approximately $+2.0 \mathrm{Mwt} / \mathrm{min}$ during the power run-up, and a maximum of $-2.0 \mathrm{Mwt} / \mathrm{min}$ during run-down. The recorded signal contained noise such as that described in the 13.3-Mwt test.

\section{c. Core Outlet Temperature (TE-115)}

The reading of TE-115-9 was $526 \mathrm{~F}$ before power run-up. With power run-up, the temperature rose smoothly to $544 \mathrm{~F}$ in approximately $700 \mathrm{sec}$. The maximum rate of change of temperature was about 2. $4 \mathrm{~F} / \mathrm{min}$. On power run-down, the temperature dipped to $524 \mathrm{~F}$, and then rose to $526 \mathrm{~F}$ after $900 \mathrm{sec}$.

\section{d. Reactor Outlet Temperature (TE-201)}

The reading of TE-201-3 was $522 \mathrm{~F}$ up to the start of the test. With run-up in power, the temperature rose to $535 \mathrm{~F}, 940 \mathrm{sec}$ after start of the power increase. On run-down, the power decreased to $522 \mathrm{~F}$ and leveled-off at that value at the end of the test about $900 \mathrm{sec}$ after start of the run-down. The maximum rate of change of temperature was 1. $5 \mathrm{~F} / \mathrm{min}$, or $90 \mathrm{~F} / \mathrm{hr}$.

\section{e. Steam Generator Sodium Inlet Temperature (TE-308)}

Up to the start of power run-up, the reading of TE-308-3 was $512 \mathrm{~F}$. On run-up, the reading rose to $521 \mathrm{~F}$ in about $940 \mathrm{sec}$. On power run-down, TE-308-3 decreased smoothly and leveled off at $515 \mathrm{~F}$ about 900 sec after start of the run-down. The maximum rate of change of temperature measured approximately $0.4 \mathrm{~F} / \mathrm{min}$. 


\section{f. Reactor Inlet Sodium Temperature (TE-209)}

Before start of the test, TE-209-3 read $513 \mathrm{~F}$. On power run-up, the temperature started to rise about $600 \mathrm{sec}$ after start of the power increase and rose to $514 \mathrm{~F}$ about $700 \mathrm{sec}$ later. On run-down, the temperature decreased to $513 \mathrm{~F}$ and leveled off at that value.

\section{g. Steam Generator Sodium Outlet Temperature (TE-301)}

At the start of the test, the reading of TE-301-1C was $520 \mathrm{~F}$. With the power increase, TE-301-1C rose to $525 \mathrm{~F}$ about $900 \mathrm{sec}$ after start of the power increase, and on run-down of power the temperature returned to $520 \mathrm{~F}$, at which point it leveled off.

\section{h. Steam Generator Steam and Water Temperature (TE-601)}

Leading up to the test, the reading of TE-601-3 was $535 \mathrm{~F}$. During the power increase, the temperature read on TE-601-3 decreased to $531 \mathrm{~F}$ about $900 \mathrm{sec}$ after start of the power increase and it remained at that level until run-down of power. After run-down, the temperature reached $534 \mathrm{~F}$,where it leveled off.

\section{i. Regulator Rod Position, Velocity, and Velocity Demand}

At the start of the test, the control rod position was 3.76 in. During programmer operation, the rod withdrew to $4.74 \mathrm{in}$. on power runup, and then it moved back to the starting position at the end of the power run-down.

The velocity and velocity demand signals reached maximums of approximately $0.31 \mathrm{in} / \mathrm{min}$ during the run-up and run-down.

j. Temperature Error $\left(T_{I}-T_{A}\right)$

Upon setting the demand for $545 \mathrm{~F}$, the error signal from the programmer rose as a ramp function to a magnitude of $+4 \mathrm{~F}$ in about $220 \mathrm{sec}$, and diminished to zero as TE-201 reached the set level. On power run-down, the error signal increased to $-4 \mathrm{~F}$, then decreased to zero as the reactor power reached the set temperature.

\section{3. $110-$ Mwt Test}

This test was conducted with the plant operating on three coolant circuits 。 


\section{a. Neutron Flux}

The power level before start of the power run-up was $10 \mathrm{Mwt}$ $\left(0.35 \times 10^{-5} \mathrm{amp}\right)$. Over a period of $80 \mathrm{~min}$ the power rose to $110 \mathrm{Mwt}$ ( $3.27 \times 10^{-5} \mathrm{amp}$ ), and was held there for about $160 \mathrm{~min}$. After the hold period, run-down was started and power was reduced to essentially $10 \mathrm{Mwt}$ over a period of 80 minutes. No plant instability was noted throughout the run-up, hold, and power run-down. The maximum rate of change of power was $1.25 \mathrm{Mwt} / \mathrm{min}$.

b. Neutron Flux Rate-of-Change

This parameter was not recorded during the 110-Mwt test.

c. Core Outlet Temperature (TE-115)

Prior to start of the power run-up, TE-115-9 read $548 \mathrm{~F}$. Simultaneously with start of the power increase, the reading of TE-115-9 began to rise, reaching $746 \mathrm{~F}$ when the power level corresponding to the demand temperature was reached. The maximum rate of temperature rise was $2.5 \mathrm{~F} / \mathrm{min}$. After setting the temperature for power run-down, the reading of TE-115-9 decreased from $746 \mathrm{~F}$ to $515 \mathrm{~F}$ in $1 \mathrm{hr}-17 \mathrm{~min}$.

\section{d. Reactor Outlet Temperature (TE-201)}

Before start of the test, the steady-state reading of TE-201-2 was $530 \mathrm{~F}$. Upon start of the programmer for power run-up, the temperature rose in the manner of a smooth ramp function, reaching $659 \mathrm{~F}$ in about 80 minutes. The maximum rate of change of temperature observed during the power increase was $1.7 \mathrm{~F} / \mathrm{min}$. On run-down, the temperature decreased with power until the level-off value of $518 \mathrm{~F}$ was reached in 80 min.

\section{e. Steam Generator Sodium Inlet Temperature (TE-308)}

Before start of the power increase, TE-308-2 read about $520 \mathrm{~F}$. With the power increase, TE-308-2 rose smoothly along with reactor power to $626 \mathrm{~F}$. With the power decrease, the temperature dropped off smoothly to the level-off value of $516 \mathrm{~F}$.

\section{f. Reactor Inlet Sodium Temperature (TE-209)}

Before start of the programmed power increase, TE-209-2 read $510 \mathrm{~F}$. With the power increase, the reading rose smoothly to $536 \mathrm{~F}$. With return to low power, the temperature decreased to $508 \mathrm{~F}$ in a smooth ramp function uniformly with reactor power. 


\section{g. Steam Generator Sodium Outlet Temperature (TE-301)}

Before start of the power run-up, the reading of TE-301-2D2 was about $515 \mathrm{~F}$. The recorded trace was noisy, and had a width of about $5 \mathrm{~F}$. With the power run-up, the temperature rose to about $525 \mathrm{~F}$, at which point the feedwater flow was increased. Upon increase of feedwater flow, TE-301-2D2 decreased to $510 \mathrm{~F}$ where it remained throughout the remainder of the test.

\section{h. Steam Generator Steam and Water Temperature (TE-601)}

Before power run-up, the reading of TE-601-2 was $518 \mathrm{~F}$. With the increase in power, the temperature rose to about $540 \mathrm{~F}$, the saturation temperature for the steam pressure at the time of the test, where it remained until power run-down. After run-down, TE-601-2 decreased to $518 \mathrm{~F}$, at which point the reactor was shut down. Throughout the test, the recorded trace was smooth and free of fluctuations.

i. Regulator Rod and Shim Rod Position

Before power run-up, the regulator rod position was at 6.8 in. As the power rose toward the 110-Mwt level, the following actions took place. The regulator rod withdrew to the 9-in. position, at which point the power had risen to about $53 \mathrm{Mwt}$. The rod speed was $0.06 \mathrm{in.} / \mathrm{min}$ during its travel. Then the shim rod moved outwardly a distance of $3.4 \mathrm{in}$. at $0.31 \mathrm{in.} / \mathrm{min}$, and the regulator rod moved inwardly to the 7 -in. position. While the shim rod remained at the 3.4 -in. position, the regulator rod withdrew to the 9 -in. position at $0.06 \mathrm{in.} / \mathrm{min}$. The shim rod then moved outwardly to approximately the $6-$ in. position at about $0.31 \mathrm{in} . / \mathrm{min}$. The regulator rod moved from the 7-in. position to the 7.4-in. position at about $0.06 \mathrm{in} / \mathrm{min}$ after the power reached the maximum level. The shim and regulator rods remained in their respective positions until start of the power run-down. On run-down, the regulator rod went to the 5-in. position and the shim rod moved from the 6-in. position to the 3.4-in. position. The regulator rod then moved to the 7 -in. position 6 min later, and then to the 5 -in. position. The shim rod went to the minus $1-i n$. position in approximately 7 min. The decrease of power continued with movement of the regulator rod to the 0 -inch position.

$$
\text { j. Temperature Error }\left(T_{I^{-}}-T_{A}\right)
$$

The temperature error signal rose to $+4 \mathrm{~F}$ with the setting for the power run-up. In the first 4-in. movement of the shim rod the error decreased to about $2 \mathrm{~F}$. After the shim rod assumed the new position, the error returned to approximately $4 \mathrm{~F}$. During run-down of power, the temperature error became $-4 \mathrm{~F}$, and then diminished to zero as the reactor returned to $10 \mathrm{Mwt}$. 


\section{k. Feedwater Flow}

The feedwater flow as measured in circuit No. 2 was about $0.84 \times 10^{5} \mathrm{lb} / \mathrm{hr}$ before power run-up. At about the time the temperature of the steam generator inlet sodium began to increase, the water flow rate was raised to $1.5 \times 10^{5} \mathrm{lb} / \mathrm{hr}$. After reduction of power, the water flow was reduced to $0.3 \times 10^{5} \mathrm{lb} / \mathrm{hr}$.

\section{B. ANALYSIS}

The relationship of reactor power and reactor outlet temperature with time obtained during programmed run-up to $110 \mathrm{Mwt}$, and a comparison with the calculated schedules are shown in Fig. 8. The calculated schedules of power and temperature of Fig. 8 were replotted from the corresponding schedules of Fig. 7 which were obtained from Ref. 1, Vol. 2. Breakover of the power curve to the slow rate at about $80 \mathrm{Mwt}$ was not obtained because superheat conditions were not recorded during the test. It has thus been demonstrated that a fast plant loading program is achieved which is consistent with established dynamic limits for the temperature parameters. Programmer operation at power levels as low as $8 \mathrm{Mwt}$ was obtained with good system stability, although a small degree of system oscillation, but well damped, was evident. System performance under programmer-controlled approach to $110 \mathrm{Mwt}$ was satisfactory, with level-off being nonoscillatory after reaching the test power level. Measurement of recorded traces of the 13.3- and 20-Mwt tests show the rates of change of power and temperature also to be within the theoretical rates. No spurious scrams or other operating difficulties were experienced during the test runs. 


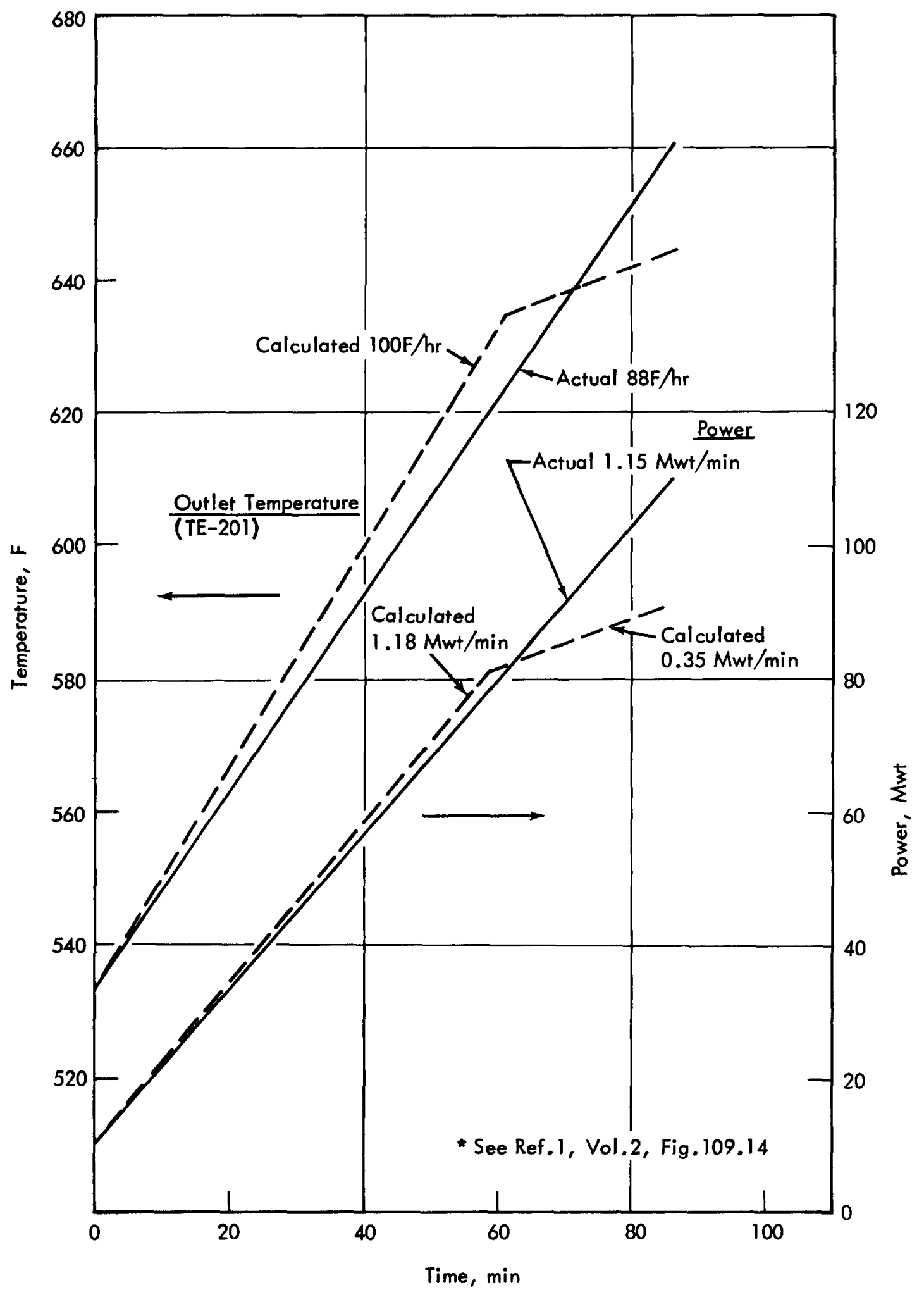

FIG. 8 REACTOR POWER AND OUTLET TEMPERATURE SCHEDULES OBTAINED IN 030269 PROGRAMMED RUN-UP TO 110 MWt, AND COMPARISON WITH CALCULATED* SCHEDULES 


\section{CONCLUSIONS}

The test of the Enrico Fermi reactor for approach to power by automatic control has been completed with satisfactory results. Although a small but well-damped oscillatory condition was evident in the parameter responses in the 13.3- and 20-Mwt tests, reactor control was found highly stable in the 110-Mwt test. The rates of change of power and temperature were well in accordance with design values. 
$\bullet$ 


\section{REFERENCES}

1. "Technical Information and Hazards Summary Report, Enrico Fermi Atomic Power Plant," Vols. 1-7, Power Reactor Development Company, Revised March 1064.

2. Wilber, H. A., "Enrico Fermi Nuclear Test Procedure No. 29, Approach to Power on Automatic Control, "Atomic Power Development Associates, Inc., September 10, 1962.

3. Ziniuk, M. A., and Wilber, H. A., "Scrarn Tests to Determine Shutdown Transient Characteristics of the Enrico Fermi Reactor and Associated Heat Transport System," APDA-NTS-15, April 1968.

4. Page, E. M., and Horne, R. E., "Flux Mapping Measurements to Determine the Location of the Permarent Detectors in the Enrico Fermi Reactor," APDA-NTS-8, September 1966. 